\title{
Antibacterial Potential of Jatropha curcas Synthesized Silver Nanoparticles against Food Borne Pathogens
}

\author{
Nitin Chauhan ${ }^{1}$, Amit K. Tyagi ${ }^{1,2}$, Pushpendar Kumar ${ }^{1}$ and Anushree Malik ${ }^{1 *}$ \\ 'Applied Microbiology Laboratory, Centre for Rural Development and Technology, Indian Institute of Technology Delhi, \\ New Delhi, India, ${ }^{2}$ Cytokine Research Laboratory, Department of Experimental Therapeutics, The University of Texas MD \\ Anderson Cancer Centre, Houston, TX, USA
}

OPEN ACCESS

Edited by: Andrea Gomez-Zavaglia,

Center for Research and Development in Food Cryotechnology (CIDCA, CONICET), Argentina

Reviewed by:

Claudia Cascio,

Wageningen University and Research

Centre, Netherlands

Rui Miguel Magalhães,

Universidade Católica Portuguesa,

Portugal

${ }^{*}$ Correspondence:

Anushree Malik

anushree@rdat.iitd.ac.in;

anushree_malik@yahoo.com

Specialty section:

This article was submitted to

Food Microbiology,

a section of the journal

Frontiers in Microbiology

Received: 01 February 2016

Accepted: 19 October 2016

Published: 08 November 2016

Citation:

Chauhan N, Tyagi AK, Kumar P and Malik A (2016) Antibacterial Potential of Jatropha curcas Synthesized Silver Nanoparticles against Food Borne Pathogens. Front. Microbiol. 7:1748. doi: 10.3389/fmicb.2016.01748
The aqueous leaf extract of Jatropha curcas was used for the synthesis of silver nanoparticles (Jc-AgNps) which were further evaluated for its antibacterial potential against food borne pathogens. J. curcas leaf extract could synthesize stable silver nanoparticles (Zeta potential: $-23.4 \mathrm{mV}$ ) with absorption band at $430 \mathrm{~nm}$. Fourier transform infrared spectroscopy indicated various biological compounds responsible for capping and stabilizing Jc-AgNps in suspension, while the presence of silver was authenticated by scanning electron microscopy (SEM) equipped with energydispersive X-ray. Jc-AgNps were confirmed to be uniform in shape, size and behavior through dynamic light scattering, transmission electron microscopy (TEM), X-ray diffraction, SEM, and atomic force microscopy (AFM) analysis. To investigate the antibacterial activity, disk diffusion and microplate dilution assays were performed and zone of inhibition (ZOI) as well as minimum inhibitory/bactericidal concentrations (MIC/MBCs) were evaluated against selected bacterial strains. Overall results showed that Escherichia coli (ZOI: $23 \mathrm{~mm}, \mathrm{MBC}: 0.010 \mathrm{mg} / \mathrm{ml}$ ) was the most sensitive organism, whereas Staphylococcus aureus (ZOI: $14.66 \mathrm{~mm}, \mathrm{MBC}: 0.041 \mathrm{mg} / \mathrm{ml}$ ) and Salmonella enterica (ZOI: $16.66 \mathrm{~mm}, \mathrm{MBC}: 0.041 \mathrm{mg} / \mathrm{ml}$ ) were the least sensitive against Jc-AgNps. The detailed microscopic investigations using SEM, TEM, and AFM were performed to understand the antibacterial impacts of Jc-AgNps against Listeria monocytogenes. SEM and TEM analysis showed the clear deformation and disintegration of treated L. monocytogenes cells, whereas AFM established a decrease in the height and cell surface roughness (root mean square value) in the treated $L$. monocytogenes.

Keywords: Jatropha curcas, silver nanoparticles, antibacterial, Listeria monocytogenes

\section{INTRODUCTION}

Nanotechnology has already been applied in various fields such as electronics (Daniel and Astruc, 2004), optics (Porel et al., 2005), catalysis (Tsunoyama et al., 2004; Behera and Ram, 2013), medicine (Singh et al., 2008), and environment remediation (Afkhami and Moosavi, 2010; Abbassi et al., 2013). However, its use in the food industry, especially as antimicrobial agent for food borne pathogens, is just beginning to develop. In food industries, nanoparticles with proven 
antimicrobial efficacy against food spoiling microbes can find valuable application. Among the studied nanoparticles, silver being the efficient antimicrobial agent, is attracting the researchers to design and develop the ways for its proper delivery and efficient action (Yeo and Jeong, 2003; Samuel and Guggenbichler, 2004). Green synthesis of silver nanoparticles (AgNps) is considered advantageous over chemical or physical methods due to simple, cost effective, and considerably safe production methodology (Gurunathan et al., 2013; Hebbalalu et al., 2013; de Faria et al., 2014). Microbes or plants can be employed for the green synthesis. However, due to various hurdles associated with the maintenance of pure microbial cultures, plants are considered as the best candidates for synthesis of AgNps (Ahmed et al., 2016).

Recent studies have highlighted the antibacterial activity of plant based AgNps against broad range of Gram-positive and Gram-negative bacteria (Jayaprakash et al., 2014; Salem et al., 2014; Muthukrishnan et al., 2015; Rajakannu et al., 2015; Sre et al., 2015). Although the actual mechanism of AgNps functioning is not yet clear, researchers believe that AgNps interact with thiol group of bacterial proteins (Lok et al., 2006) and phosphorous moieties of DNA (Rai et al., 2009) to inactivate the bacterial cell system. It was also reported that nano-silver is non-toxic to humans at low doses (Wen et al., 2007; Tankhiwale and Bajpai, 2009). Thereafter, few attempts were made to develop AgNps coated systems, especially for food preservation against lethal food borne pathogens. Tankhiwale and Bajpai (2009) used the graft copolymerization of vinyl monomers onto cellulose based filter paper followed by entrapment of AgNps. The developed nano-silver based food packaging was found to be effective against Escherichia coli. Similarly, AgNps incorporated onto hydroxypropyl methylcellulose (HPMC) matrix were found to show antibacterial activity against E. coli and Staphylococcus aureus (De Moura et al., 2012). However, these materials have employed chemical/physical methods for synthesis and stabilization of AgNps. Therefore, green routes for AgNps synthesis and subsequent development of such systems is the need of the hour.

Jatropha curcas (Euphorbiaceae) is widely cultivated for commercial scale bio diesel production from its seeds (Berchmans and Hirata, 2008; Tapanes et al., 2008). J. curcas latex has been reported for the medicinal uses like wound healing and blood coagulant activity (Osoniyi and Onajobi, 2003). The leaf extract of $J$. curcas was also reported for insecticidal and antimicrobial properties (Kalimuthu et al., 2010; Verma et al., 2013; Chauhan et al., 2015). Moreover, J. curcas leaf extract has recently been used for the synthesis of AgNps, however, no antimicrobial properties were investigated (Rajasekharreddy et al., 2010). Therefore, in the present study, an attempt was made to synthesize the AgNps from aqueous leaf extract of $J$. curcas and to study the antimicrobial activity of J. curcas leaf synthesized silver nanoparticles (Jc-AgNps) against various food borne pathogens including Gram-positive (Bacillus cereus, Staphylococcus aureus, Listeria monocytogenes) and Gramnegative bacteria (Escherichia coli, Pseudomonas aeruginosa, Salmonella enterica). Since few studies have highlighted the interaction of AgNps with bacterial cells and subsequent cell damage, (Sondi and Salopek-Sondi, 2004; Morones et al., 2005; Kim et al., 2011; Das et al., 2015), these aspects were investigated in the current study. A detailed microscopic analysis of food borne pathogen L. monocytogenes was carried out using scanning electron microscopy (SEM), transmission electron microscopy (TEM), and atomic force microscopy (AFM) techniques to visualize the impact of Jc-AgNps on cell morphology and ultrastructure. To the best of author's knowledge, this is the first report to visualize the effect of Jc-AgNps on the morphology of L. monocytogenes cells through various microscopic analysis, thereby strengthening the approach of "AgNps green synthesis" for designing safe and active materials for food preservation.

\section{MATERIALS AND METHODS}

\section{Chemicals}

Silver nitrate used in the study was of analytical grade purchased from Merck, India. Mueller-Hinton broth and Mueller-Hinton agar for antimicrobial activity were purchased from Hi-Media, Mumbai, India. The aqueous solutions were prepared using ultra filtered water (resistivity: $18.2 \mathrm{M} \Omega-\mathrm{cm}$ ).

\section{Plant Sample Collection and Extract Preparation}

Disease-free, healthy leaves of Jatropa curcas were collected during the month of May in 2012 from Micro model complex, Indian Institute of Technology Delhi, New Delhi, India. The collected leaves were washed thoroughly with tap water and then rinsed with distilled water until no foreign material remained. Ten grams of freshly chopped leaves of J. curcas were mixed with $100 \mathrm{ml}$ of Milli Q water in a $500 \mathrm{ml}$ beaker and warmed in water bath at $60^{\circ} \mathrm{C}$ for $10 \mathrm{~min}$. The extract was filtered with filter paper (Whatman's filter paper no. 1). The filtered leaf extract was kept at $4^{\circ} \mathrm{C}$ till the synthesis of AgNps.

\section{Bio-Synthesis of Silver Nanoparticles from the Aqueous Leaf Extract of J. curcas}

Five milliliters of leaf extract was added into $45 \mathrm{ml}$ of $0.002 \mathrm{M}$ $\mathrm{AgNO}_{3}$ solution for the reduction of silver ions in a $100 \mathrm{ml}$ Erlenmeyer flask at room temperature. The reaction mixture was kept in dark room condition until the color change was initiated. The brownish-gray color of solution indicated the formation of the silver nanoparticles (Jc-AgNPs). The bioreduction of the silver ions was monitored through the UVvisible spectroscopy $(300-700 \mathrm{~nm})$ of the solutions. The watersuspended nanoparticles were frozen $\left(-40^{\circ} \mathrm{C}\right)$ for $24 \mathrm{~h}$ prior to lyophilisation. The frozen samples were lyophilised (Allied frost FD-3) under $-80^{\circ} \mathrm{C}$ for 2 days. The structure and composition of lyophilised Jc-AgNPs were evaluated by SEM, TEM, AFM, energy-dispersive X-ray (EDX), and fourier transform infra-red spectroscopy (FTIR) and X-ray diffraction (XRD). 


\section{Characterization of Jc-AgNPs UV-vis Spectra Analysis}

The reduction of silver ions was observed by measuring the UV-vis spectrum with Perkin Elmer Preclsley, Lambda 35 Spectrophotometer operated at a resolution of $\pm 1 \mathrm{~nm}$ at different time intervals (Roy et al., 2014). UV-vis spectroscopic analysis was performed by continuous scanning from 300 to $700 \mathrm{~nm}$ and $0.002 \mathrm{M} \mathrm{AgNO}_{3}$ solution was used for the baseline correction.

\section{Quantification of Jc-AgNps}

The sample of Jc-AgNps $(1 \mathrm{mg} / \mathrm{ml})$ was digested in microwave digestion $\left(160 \pm 4^{\circ} \mathrm{C}\right.$ within $10 \mathrm{~min}$ and $165-170^{\circ} \mathrm{C}$ for $10 \mathrm{~min}$ for reaction) and analyzed further for quantification of AgNps concentration using Microwave plasma-atomic emission spectrometry (Agilent $4200 \mathrm{MP}-\mathrm{AES}$ ) (Gola et al., 2016). The conditions for MP-AES were maintained as (i) Nebulizer flow: $0.65 \mathrm{~L} / \mathrm{min}$ (ii) Stabilization time: $15 \mathrm{~s}$ (iii) Read time: $3 \mathrm{~s}$ (iv) Pump speed: $15 \mathrm{rpm}$, (v) Background correction: Auto (v) Analyte (wavelength): Ag (328.06 nm).

\section{SEM and EDX Analysis}

The lyophilised Jc-AgNPs were characterized for nanoparticles shape with a scanning electron microscope (ZEISS EVO 50). EDX analysis was conducted with the same instrument to confirm the presence and elemental composition of the synthesized sample as described before (Forough and Farhadi, 2010).

\section{TEM Analysis}

The drop of purified aqueous Jc-AgNps sample was loaded on carbon-coated copper grid and it was allowed to dry at room temperature for $4 \mathrm{~h}$. The TEM micrograph images were recorded on Philips transmission electron microscope (CM-10) on carbon coated copper grids with an accelerating voltage of $70 \mathrm{kV}$ (Balaji et al., 2009). The clear microscopic views were observed and documented at different range of magnifications.

\section{AFM Analysis}

Further to analyze the particle size and characterization of these nanoparticles, AFM was used (Dwivedi et al., 2011; Prathna et al., 2011). The microscopic images were recorded with silicon cantilever with force constant $0.22-0.77 \mathrm{~N} / \mathrm{m}$, tip height $10-$ $12 \mathrm{~nm}$ in the contact mode. The Jc-AgNps were studied in three dimensional views with various other structural parameters.

\section{FTIR Analysis}

To identify the biomolecules present in the Jc-AgNPs after the synthesis of the AgNps, FTIR spectra of lyophilised Jc-AgNPs powder were analyzed by FTIR spectroscopy (Perkin Elmer One spectrum) (Prathna et al., 2011). The FTIR analysis was performed with $\mathrm{KBr}$ pellets. The FTIR was recorded in a diffuse reflection mode at a resolution of $4 \mathrm{~cm}^{-1}$. The various modes of vibrations were identified to determine the different functional groups present in the Jc-AgNPs.

\section{X-ray Diffraction (XRD) Measurement}

Crystalline metallic silver was also examined by XRD using X' Pert PRO Philips Analytical-PW 3040/60 X ray diffractometer with a $\mathrm{CuK} \alpha$-radiation monochromatic filter in the range $35-80^{\circ}$.

\section{Zeta Potential ( $\zeta$-potential) and Dynamic Light Scattering (DLS) Measurements}

The particle size distribution and $\zeta$-potential of the Jc-AgNps solutions were measured using a particle analyzer (Nano ZS90 Zetasizer, Malvern Instruments, UK) equipped with a $\mathrm{He}-\mathrm{Ne}$ laser (633 nm, $5 \mathrm{~mW}$ ) (Edison and Sethuraman, 2012). The numbers of measurements were optimized automatically by the software.

\section{Bacterial Culture Preparation}

Bacterial strain such as Escherichia coli (ATCC 25922), Pseudomonas aeruginosa (ATCC 9027), Salmonella enterica Serovar Enteritidis (ISO 155), Bacillus cereus (ATCC 11966), Staphylococcus aureus (SR 231), were collected from the Central Microbial Culture Facility, Department of Biotechnology and Biochemical Engineering, Indian Institute of Technology Delhi, New Delhi, India, while Listeria monocytogenes (SCOTT-A) was obtained from the Strain Collection of Dipartimento di Scienze degli Alimenti, University of Bologna, Italy. The collected strains were grown in Mueller-Hinton broth (MHB) medium for $24 \mathrm{~h}$ in an orbital shaking incubator (Scigenics India Pvt. Ltd., India) at $180 \mathrm{rpm}$ and $30^{\circ} \mathrm{C}$. Cells were harvested by centrifugation $(5000 \times g, 10 \mathrm{~min})$, suspended in saline and used immediately.

\section{Antimicrobial Assays Disk Diffusion Method}

As described by Tyagi and Malik (2011), the aliquot of $100 \mu \mathrm{l}$ from each cell suspension containing approximately $10^{5} \mathrm{cfu} / \mathrm{ml}$ was spread over the surface of MHA plate and allowed to dry. The sterile paper disks (diameter $6 \mathrm{~mm}$, Sigma-Aldrich Inc., India) were placed on agar plates and 10-30 $\mu \mathrm{l}$ of Jc-AgNps solution $(0.5 \mathrm{mg} / \mathrm{ml})$ was poured on each disk. The plates were then sealed with parafilm to prevent any unwanted contamination. All the plates were incubated at $30^{\circ} \mathrm{C}$ for $24 \mathrm{~h}$ and the diameter of the resulting inhibition zone in each plate was measured. All tests were performed in triplicate.

\section{Determination of MIC and MBC by Microplate Dilution Method}

Minimum Inhibitory Concentration (MIC) and Minimum Bactericidal Concentration (MBC) of synthesized Jc-AgNps were determined by microplate dilution method. Different concentrations of $\mathrm{Jc}$-AgNps were prepared using ultrapure water and added to the microtiter wells to obtain the final concentrations of $0.005,0.010,0.020,0.041,0.083,0.166$, and $0.333 \mathrm{mg} / \mathrm{ml}$. The components such as MHB media (100 $\mu \mathrm{l})$; $1 \times 10^{5}$ bacterial culture $(100 \mu \mathrm{l})$; different concentrations $(0.005-$ $0.333 \mathrm{mg} / \mathrm{ml})$ of Jc-AgNps $(100 \mu \mathrm{l})$ were added in each well of 96-well microplate (Mariselvam et al., 2014; Yehia and AlSheikh, 2014). The control sample contained every component, i.e., bacterial cells in saline and sterile distilled water without nanoparticles. Further, the microplates were incubated at $30^{\circ} \mathrm{C}$. The visual observation of the microplates for bacterial growth was performed after 24 and $48 \mathrm{~h}$ of the incubation. The MIC values were identified as the minimum concentration at which no visible bacterial growth was recorded. For MBC, an aliquot of $50 \mu \mathrm{l}$ from all the wells showing no visible bacterial growth 
were applied on MHA plates and incubated at $30^{\circ} \mathrm{C}$ for $24 \mathrm{~h}$. The MBC were observed as the lowest concentration that completely inhibited the bacteria.

\section{Characterization of Bacterial Cells}

The bacterial cells of $L$. monocytogenes and S. enterica were incubated for $14 \mathrm{~h}$ in $\mathrm{MHB}$ medium at $30^{\circ} \mathrm{C}$ and $180 \mathrm{rpm}$. L. monocytogenes cell suspension was divided into two parts. In first part (treated), the MIC concentrations, $(0.010 \mathrm{mg} / \mathrm{ml})$ was added while the second part was left untreated (control). The suspensions were incubated for $8 \mathrm{~h}$ at $30^{\circ} \mathrm{C}$. Similarly, S. enterica was treated at MIC and $1 / 2$ MIC level. All the treated and untreated cells were harvested by centrifugation and were prefixed with a $2.5 \%$ glutaraldehyde solution overnight at $4^{\circ} \mathrm{C}$. After this, the cells were again harvested by centrifugation and washed three times with $0.1 \mathrm{M}$ sodium phosphate buffer solution ( $\mathrm{pH}$ 7.2). Now each resuspension was serially dehydrated with $25,50,75,90$, and $100 \%$ ethanol, respectively. Then, cells were dried at "critical point." For SEM, a thin film of cells was smeared on a silver stub. The samples were gold-covered by cathodic spraying (Polaron gold). Finally, morphology of the L. monocytogenes and S. enterica was observed on a scanning electronic microscope (ZEISS EVO 50). The SEM observation was done under the following analytical condition: $\mathrm{EHT}=20 \mathrm{kv}$, $\mathrm{WD}=10 \mathrm{~mm}$, Signal $\mathrm{A}=\mathrm{SE}_{1}$. For TEM, the pellet was post fixed in $1 \%$ osmium tetraoxide for $30 \mathrm{~min}$, washed with phosphate buffer solution ( $\mathrm{pH}$ 7.2), serially dehydrated in ethanol and embedded in Epon-Araldite resin for making the blocks of the cells pellet. Ultra thin (50-100 nm) sections of the cells were stained with uranyl acetate with lead citrate and observed under a Philips transmission electron microscope (CM-10) at $100 \mathrm{eV}$ and direct magnification of $50000 \times$. For AFM mounting of bacterial cell (L. monocytogenes), glass substrates were employed. Ten microliters of untreated and treated bacterial cells suspension was mounted on a glass substrate. After air-drying the cells were imaged with AFM in contact mode.

\section{Statistical Analysis}

All the experiments were done in triplicate and the data presented here represents the mean of three replicates. Data related to the zone of inhibition (ZOI) were subjected to analysis of variance (one-way ANOVA) in Duncan multiple range test using SPSS (2008; version 17.5) statistical software. The differences with $p<0.05$ were considered significant.

\section{RESULTS}

The AgNps produced using aqueous leaf extract of J. curcas were characterized and its antibacterial property was evaluated against selected bacterial strains followed by the detailed microscopic characterization of the treated bacterial cells.

\section{Physical Characterization of Jc-AgNps}

UV-vis spectra confirmed the synthesis of Jc-AgNps as evident from the peak at $430 \mathrm{~nm}$ (Supplementary Figure S1B). The change in color from yellowish to deep brown with time is due to excitation in surface plasmon resonance (Supplementary Figure S1A). There is no color change in J. curcas leaf extract and $\mathrm{AgNO}_{3}$ solution alone, confirming that components from leaf extract actually reduced the metallic silver into AgNps. The $\mathrm{pH}$ of the Jc-AgNp solution was observed to be 6.8 after $72 \mathrm{~h}$. The lyophilized sample ( $1 \mathrm{mg} / \mathrm{ml}$, Jc-AgNp) was diluted (200 times) for accurate measurement before analysis through MP-AES. The calibration curve was prepared (Supplementary Figure S2A) using three different concentrations of silver (2, 6, and $8 \mathrm{ppm})$, further the analysis of the sample (Jc-AgNp) was performed. The result obtained from MP-AES analysis indicated that the stock of $1 \mathrm{mg} / \mathrm{ml}$ of Jc-AgNps has the concentration of $550 \mathrm{ppm}$ of AgNps (Supplementary Figure S2B), hence the dilutions of $0.005,0.010,0.020,0.041,0.083,0.166$, and $0.333 \mathrm{mg} / \mathrm{ml}$ used in the antibacterial experiments contained 2.75, 5.5, 11, 22.55, 45.65, 91.3, $183.15 \mathrm{ppm}$ of AgNps, respectively. The analysis such as Zeta potential and DLS were performed to determine the stability of Jc-AgNps in suspension. A negative zeta potential of Jc-AgNps $(-23.4 \mathrm{mV})$ proved the high stability of AgNps in colloidal solution (Supplementary Figure S3B). DLS analysis showed that the mean diameter of the Jc-AgNps is $43.67 \mathrm{~nm}$ (Supplementary Figure S3A) proving the nano-size of synthesized Jc-AgNps.

To assess whether these nanoparticles are crystalline in nature, XRD analysis was conducted. As shown in Supplementary Figure S3C, the diffraction peaks at $2 \theta=38.28^{\circ}, 46.25^{\circ}$, and $77.62^{\circ}$ were assigned to diffraction signals (111), (200), and (311) of face centered cubic (fcc) structures of Jc-AgNps as per the Joint Committee on Powder Diffraction Standards (JCPDS) file no: ICDD-PDF2, PA, USA, 2007. Next, to identify Jc-AgNps associated compounds, FTIR spectra was recorded. The FTIR spectra of Jc-AgNps exhibited prominent peaks at 3321, 1608, 1343, 1043, and $774 \mathrm{~cm}^{-1}$ (Supplementary Figure S3D). The peaks $1608 \mathrm{~cm}^{-1}$ represented the involvement of C-N in plane vibrations of amino-acids and $1020-1220 \mathrm{~cm}^{-1}$ represented the involvement of $\mathrm{C}-\mathrm{N}$ in plane vibrations of aliphatic amines. The presence of peaks due to $\mathrm{O}-\mathrm{H}$ stretching (around $\left.3321 \mathrm{~cm}^{-1}\right), \mathrm{C}-\mathrm{C}$ and $\mathrm{C}=\mathrm{O}$ stretching $\left(1343 \mathrm{~cm}^{-1}\right)$, $\mathrm{O}-\mathrm{H}$ stretching $\left(1043 \mathrm{~cm}^{-1}\right)$, and $\mathrm{C}-\mathrm{H}$ alkenes $\left(774 \mathrm{~cm}^{-1}\right)$ was also observed highlighting the presence of various biological compounds for stabilization of AgNps in J. curcas extract.

\section{Microscopic Evaluation of Jc-AgNps}

The lyophilized Jc-AgNps were analyzed for shape, size, and elemental composition under SEM equipped with energy dispersive X-ray spectroscopy. The diameter of nanoparticles was found to be in range of 50-100 nm, although some clumps were also observed (Figure 1A, left panel). The EDX analysis of Jc-AgNps showed strong signals $(20 \mathrm{kV})$ of silver, whereas weaker signals were recorded for other elements including oxygen, carbon, chloride, and silicon from synthesized sample (Figure 1A, right panel). The TEM analysis clearly showed variation in particle shape and size (20-50 nm; Figure 1B). While majority of the Jc-AgNps were spherical, some showed irregular shapes and edges. AFM was conducted to understand the surface properties of synthesized nanoparticles. The corresponding section analysis of Jc-AgNPs is shown in Figure 1C. The RMS value corresponds to the roughness of the sample and its value 

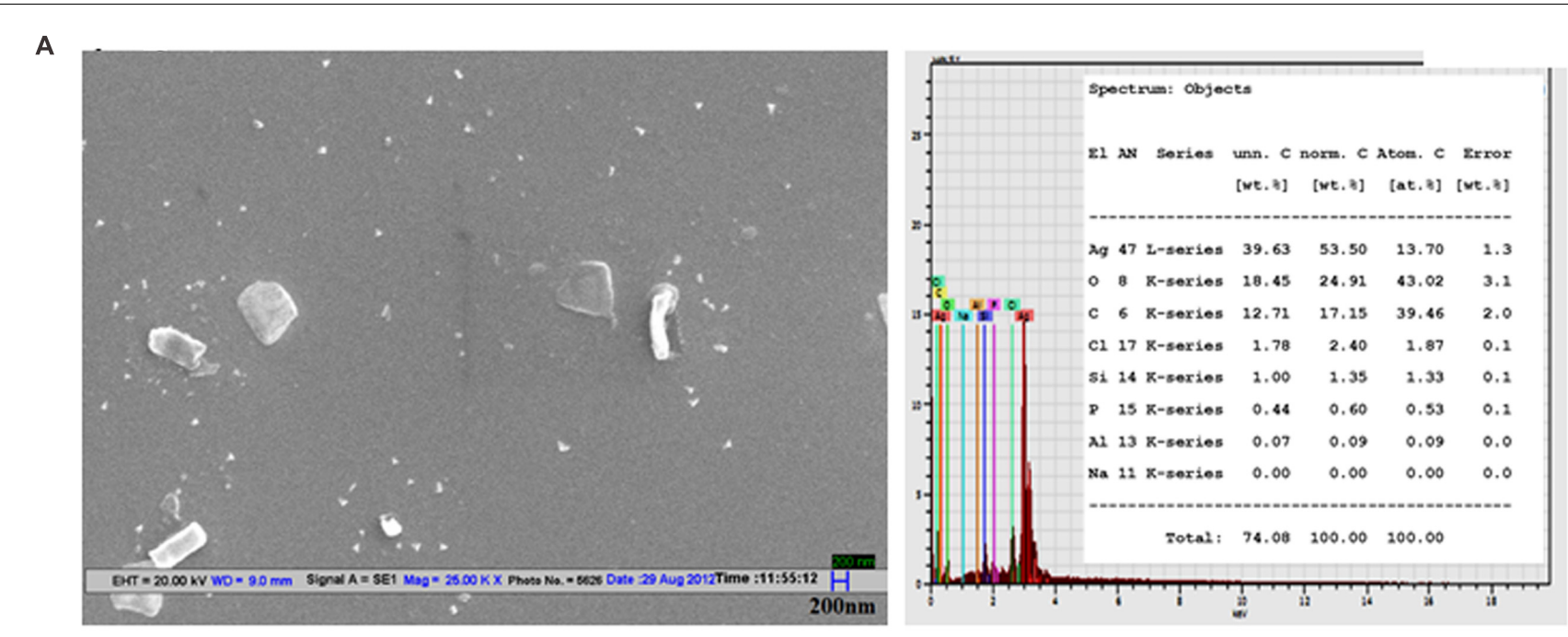

B

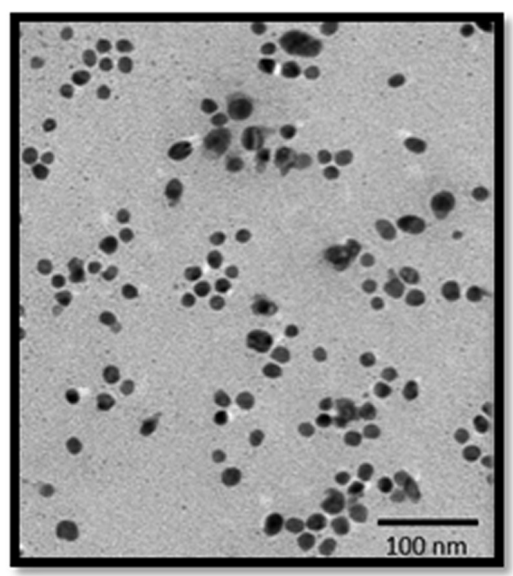

C

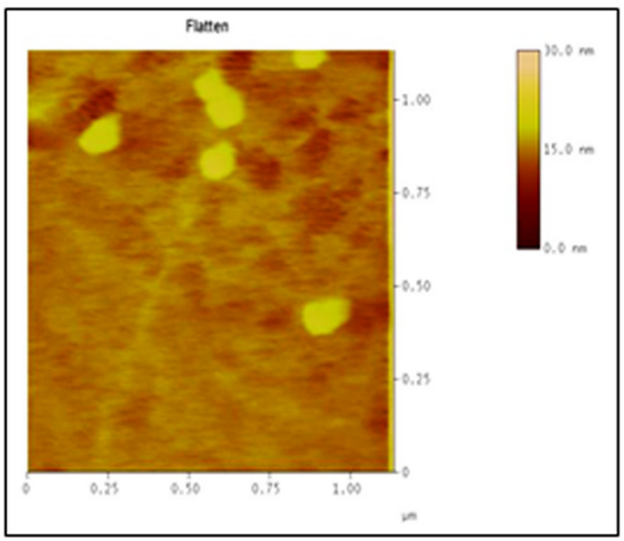

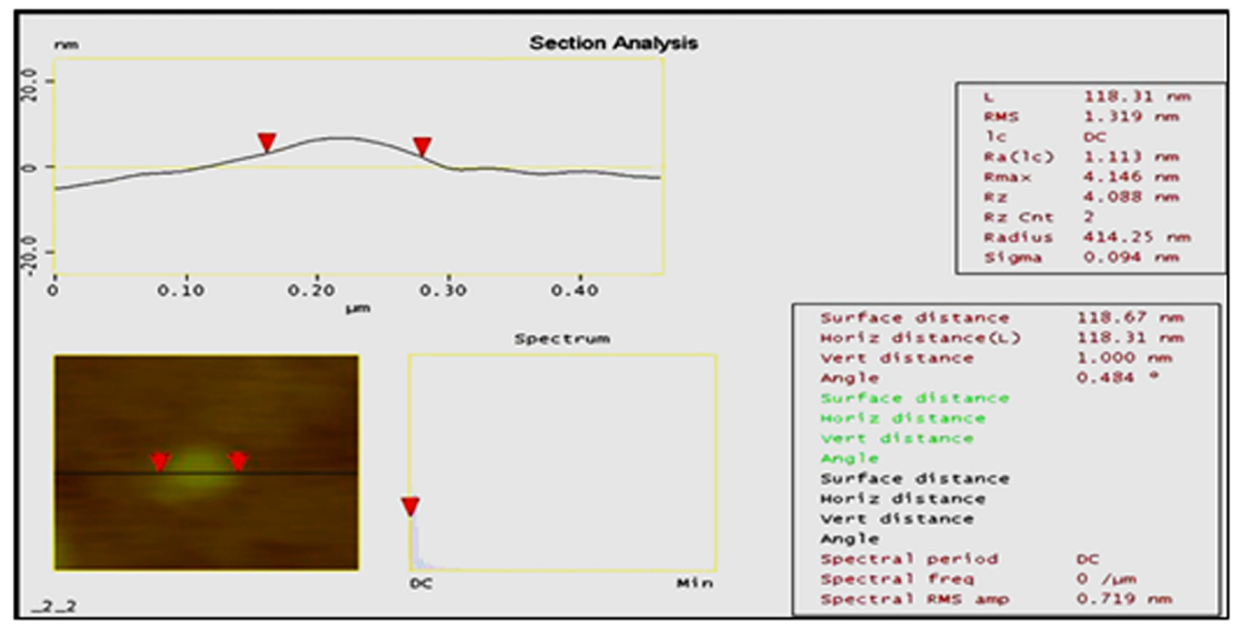

FIGURE 1 | Microscopic analysis of green synthesized Jc-AgNps. (A) Left: SEM image of Jc-AgNps showing variation in sizes (50-100 nm); Right: energy-dispersive X-ray (EDX) patterns of Jc-AgNps showing strong signals of silver (20 kV), (B) Transmission electron microscopic images of Jc-AgNPs. Images were taken at $200 \mathrm{kV}$ on a carbon-coated Cu grid, (C) AFM image showing root mean square along with major statistical parameters of Jc-AgNps. 


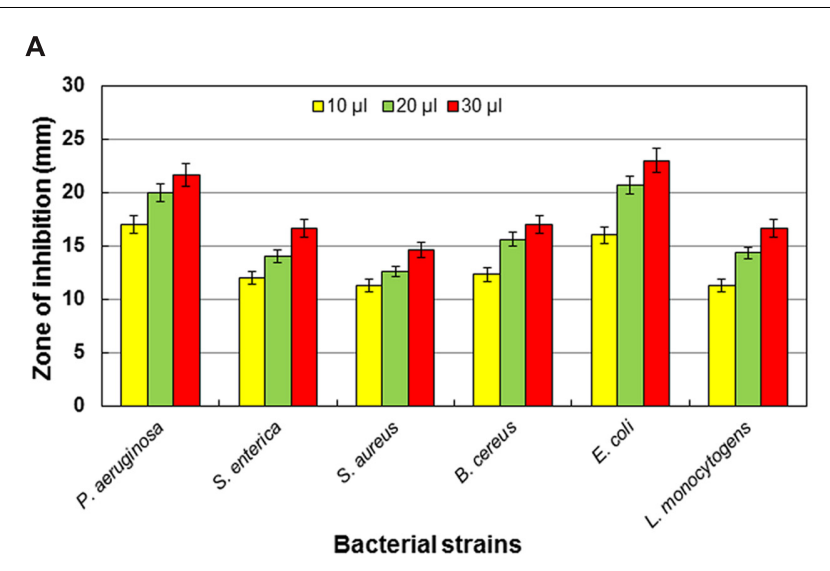

B

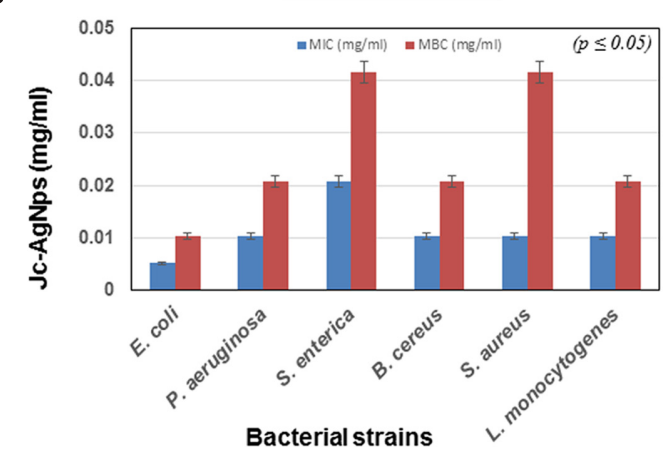

FIGURE 2 | Antibacterial activity of green synthesized Jc-AgNps. (A) Zone of inhibition (mm) due to different volumes (10, 20, and $30 \mu \mathrm{l} / \mathrm{disk}$, concentration: $0.5 \mathrm{mg} / \mathrm{ml}$ ) of Jc-AgNps against bacterial strains, (B) Minimum Inhibitory/Bactericidal Concentrations (MIC/MBCs) for different bacterial strains.

was observed to be $1.31 \mathrm{~nm}$. The analysis proved that the synthesized Jc-AgNps were $\sim 100 \mathrm{~nm}$ correlating with the results of TEM or SEM analysis.

\section{Antimicrobial Activity of Jc-AgNps Zone of Inhibition}

The antimicrobial activity of Jc-AgNps measured in terms of ZOI is shown in Figure 2A. It was observed that the ZOI increased in dose-dependent manner and followed the same trend with respect to different bacterial strains. The highest inhibitory zone (23 mm) was observed in E. coli at $30 \mu \mathrm{l}$ volume, whereas the lowest inhibitory zone $(14.6 \mathrm{~mm})$ was found with $S$. aureus. However, $P$. aeruginosa was found to be more sensitive than E. coli at $10 \mu \mathrm{l}$ volume. Based on the overall results obtained from the ZOI data, the pattern of sensitivity was observed in the order as E. coli $>$ P. aeruginosa $>$ B. cereus $>$ S. enterica $=$ L. monocytogenes $>$ S. aureus.

\section{MIC and MBC of Jc-AgNps}

The MIC and MBC values of AgNps against various Grampositive (B. cereus, S. aureus, L. monocytogenes) and Gramnegative bacteria (E. coli, $P$. aeruginosa, S. enterica) is shown in Figure 2B. For Gram-negative bacteria, the MIC varied from
0.005 to $0.020 \mathrm{mg} / \mathrm{ml}$, whereas for Gram-positive bacteria, it was found to be $0.010 \mathrm{mg} / \mathrm{ml}$. Similarly, for Gram-negative bacteria, the value of $\mathrm{MBC}$ varied between 0.010 and $0.041 \mathrm{mg} / \mathrm{ml}$ and for Gram-positive bacteria, it was observed to be 0.020 and $0.041 \mathrm{mg} / \mathrm{ml}$. The highest value of MIC $(0.020 \mathrm{mg} / \mathrm{ml})$ was observed with $S$. enterica, whereas the lowest MIC $(0.005 \mathrm{mg} / \mathrm{ml})$ was observed with E. coli. Similarly, for MBC, the highest value $(0.041 \mathrm{mg} / \mathrm{ml})$ was observed with $S$. aureus and $S$. enterica, whereas the lowest value $(0.010 \mathrm{mg} / \mathrm{ml})$ was observed with E. coli.

\section{Effect of Jc-AgNps on Bacterial Cell Morphology and Ultrastructure}

To gain insight into the interaction of Jc-AgNps with the bacterial cells leading to the cell death, detailed microscopic characterization was conducted. Gram-positive L. monocytogenes, which is the most virulent food borne pathogen, causes meningitis and is the leading cause of death among food borne pathogens (Donnelly, 2001), was selected. Gram-negative S. enterica was also studied for comparative evaluation.

Scanning electron microscopy analysis of untreated cells showed the normal and smooth surfaces of L. monocytogenes (Figure 3A), whereas the cells treated with Jc-AgNps at MIC level showed shrinkage and deformation (Figure 3B). The micrograph also depicts scattered cell debris around the cells. The SEM equipped EDX analysis confirmed the presence of silver (0.72 wt. \%) in the treated cells of L. monocytogenes (Figure 3C) establishing the role of AgNps for cell damages. Similarly, the treated cells of $S$. enterica showed dose dependent morphological deformity (at MIC and $1 / 2$ MIC) in comparison with well organized and intact morphology of untreated cells under SEM examination (Supplementary Figure S4).

Next, TEM analysis was performed to study the ultrastructure of treated and untreated L. monocytogenes cells. The untreated cells showed a well-defined cell membrane with normal intact cells and dense cytoplasm (Figure 4A). After exposure to JcAgNps at MIC level, the cell membrane was observed to be disrupted and disintegrated (Figure 4B). The cell was ruptured and showed disorganized cytoplasm with noticeable AgNps at various sites confirming the role of silver for these damages as suggested through SEM-EDX analysis.

To determine the three dimensional morphological changes along with roughness of cell surfaces in treated and untreated cells, AFM analysis was carried out. As compared to the untreated cells (Figure 5A), a clear cell damage was observed in three dimensional analysis of treated cells (Figure 5B). The height of untreated cells was found to be $1699 \mathrm{~nm}$ (Figure 5C), whereas the treated cells showed $15 \mathrm{~nm}$ height (Figure 5D) confirming the rupture and loss of rigidity in the cells. The roughness of treated and untreated bacterial cells was measured as the root mean square (rms) values. As indicated in Figures 5C,D, the treated cells showed lower rms value $(2.17 \mathrm{~nm})$ than untreated cells $(116.19 \mathrm{~nm})$. Overall, the SEM (showing morphological changes), TEM (showing ultrastructure cell damages), and AFM (showing three dimensional morphological changes) together substantiate the AgNps induced bacterial cell distortion and disintegration. 
A

B
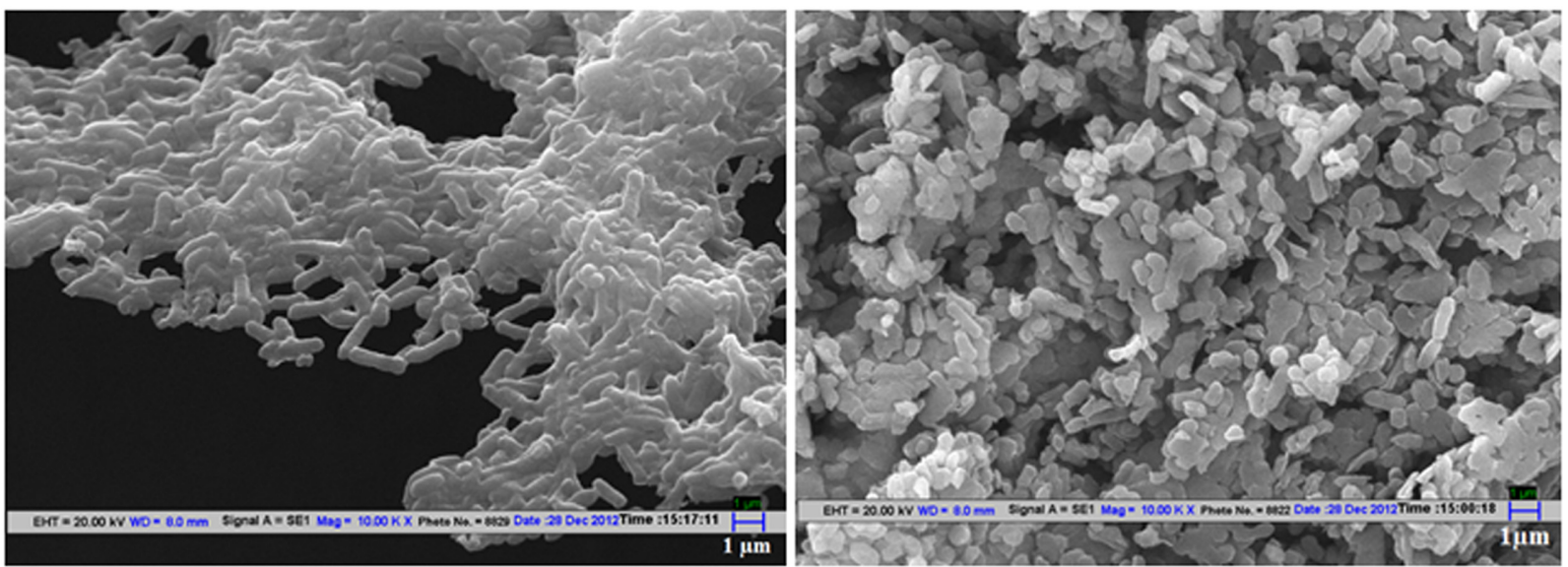

C
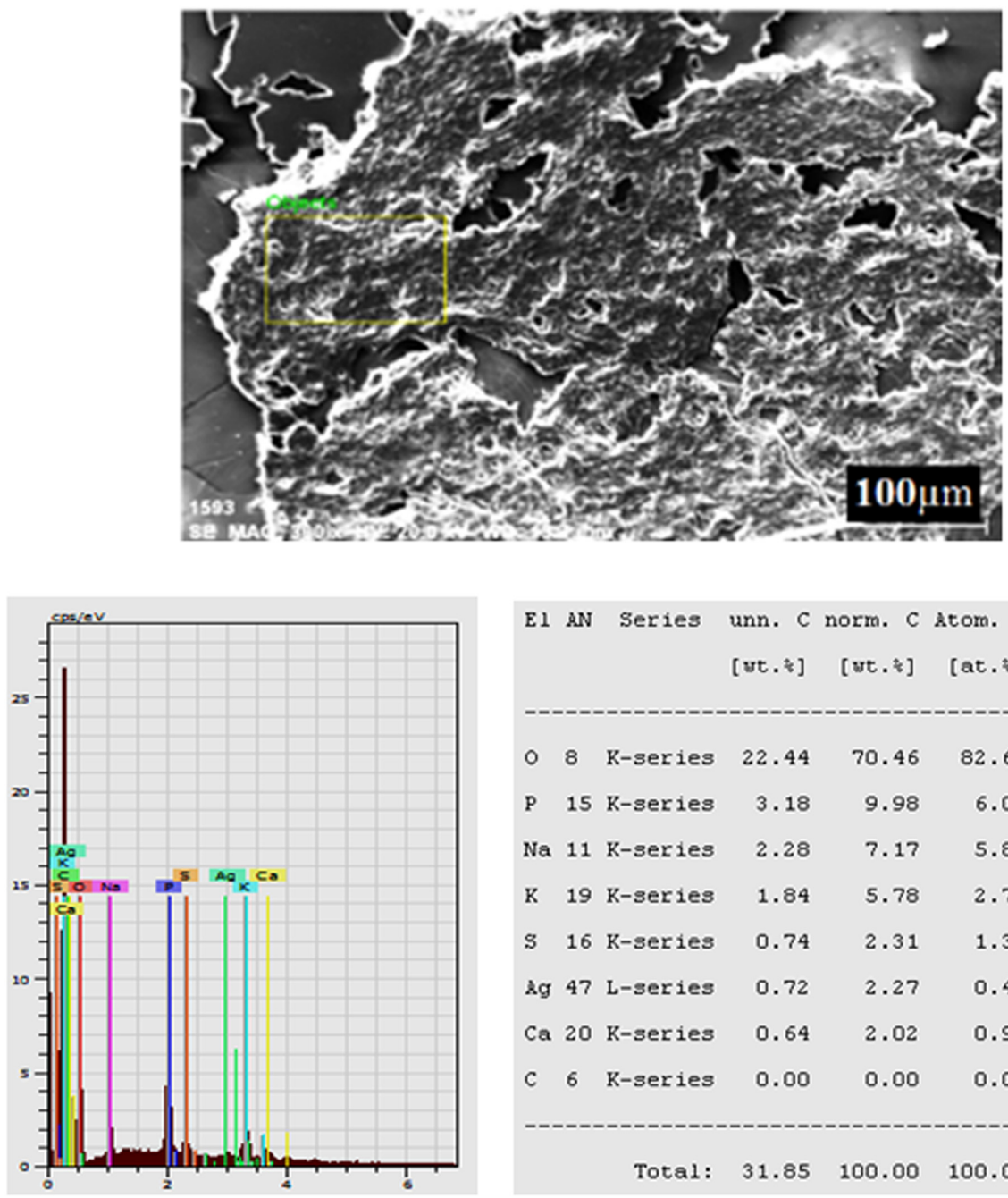

E1 AN Series unn. C norm. C Atom. C Error [ut. ₹] [wt.t] [at.i] [ut. *]

\begin{tabular}{|c|c|c|c|c|c|c|}
\hline 0 & 8 & $\mathrm{~K}$-series & 22.44 & 70.46 & 82.63 & 3.4 \\
\hline p & 15 & $\mathrm{~K}$-series & 3.18 & 9.98 & 6.04 & 0.2 \\
\hline $\mathrm{Na}$ & 11 & K-series & 2.28 & 7.17 & 5.85 & 0.2 \\
\hline $\mathrm{K}$ & 19 & $\mathrm{~K}$-series & 1.84 & 5.78 & 2.77 & 0.1 \\
\hline $\mathrm{s}$ & 16 & $\mathrm{~K}$-series & 0.74 & 2.31 & 1.35 & 0.1 \\
\hline $\mathrm{Ag}$ & 47 & L-series & 0.72 & 2.27 & 0.40 & 0.1 \\
\hline $\mathrm{Ca}$ & 20 & $\mathrm{~K}$-series & 0.64 & 2.02 & 0.95 & 0.1 \\
\hline c & 6 & $\mathrm{~K}$-series & 0.00 & 0.00 & 0.00 & 0.0 \\
\hline
\end{tabular}

FIGURE 3 | Scanning electron microscopic (SEM) analysis. (A) SEM micrograph of untreated Listeria monocytogenes cells showing normal and smooth surface, (B) SEM micrograph of Jc-AgNps treated L. monocytogenes cells showing shrinkage and deformation, (C) SEM-EDX analysis of treated L. monocytogenes cells (silver: 0.72 wt.\%). 
A

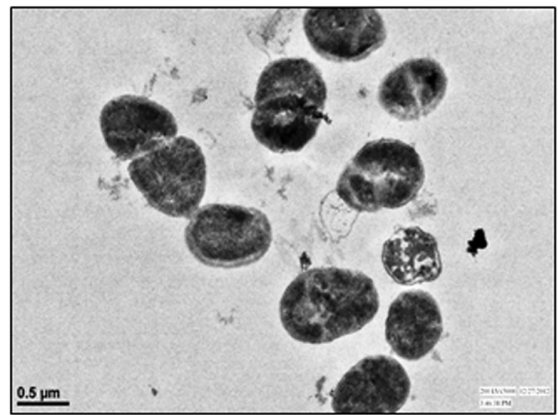

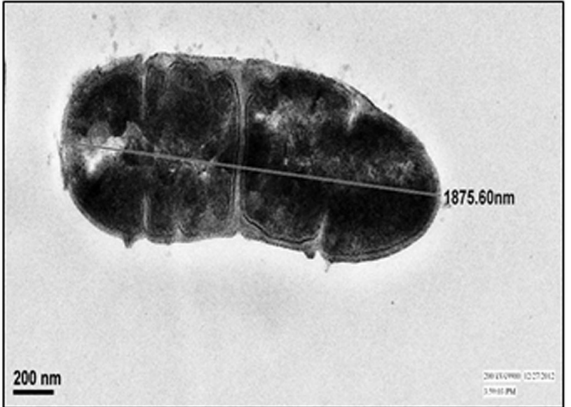

$200 \mathrm{~nm}$

B

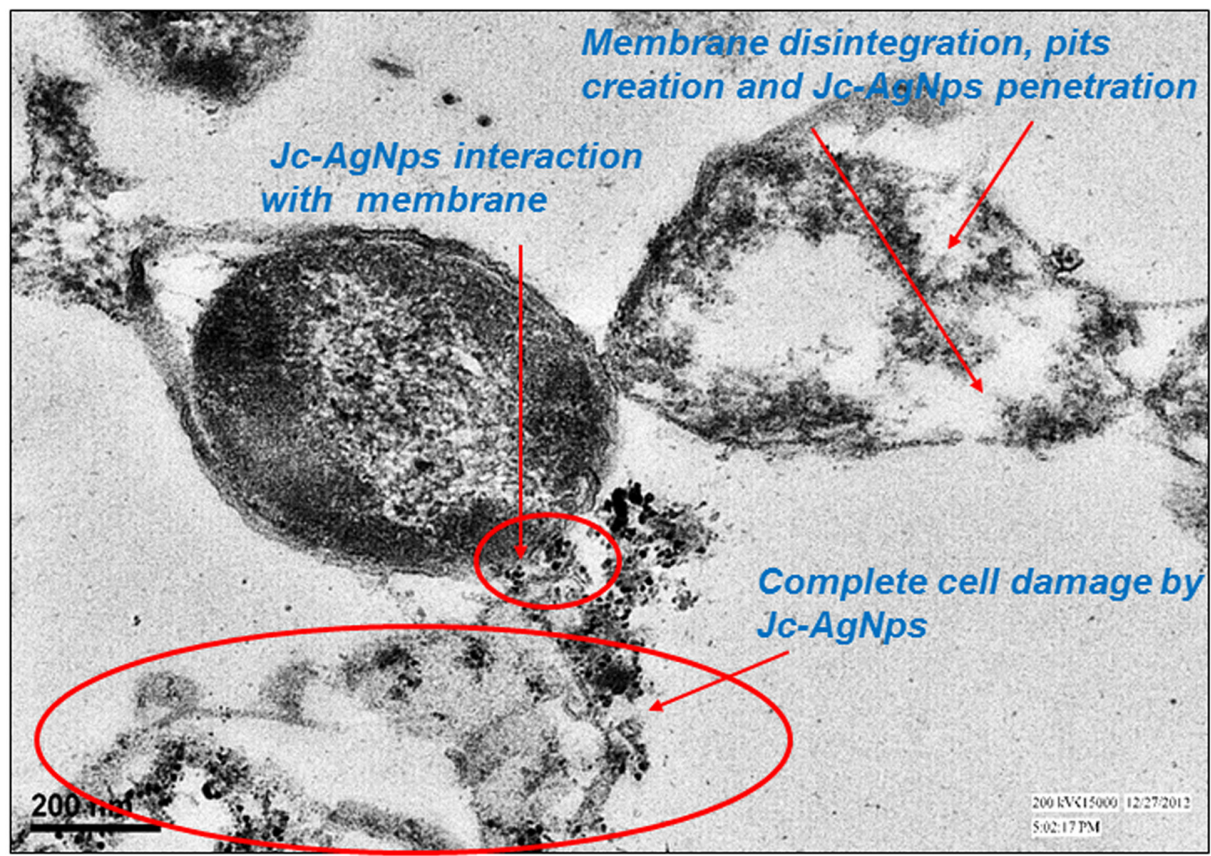

FIGURE 4 | Transmission electron microscopic (TEM) examination. (A) TEM micrograph of untreated L. monocytogenes cells showing normal membrane and intact cell, (B) TEM micrograph of Jc-AgNps treated L. monocytogenes cells showing biocidal actions including; Jc-AgNps adherence and interaction with membrane; Membrane disintegration, pits creation and complete cell damage.

\section{DISCUSSION}

The synthesis of AgNps through J. curcas leaf extract exhibited a time dependent color change correlated with the peaks obtained with UV-vis spectroscopy. The main advantage of using plants for $\mathrm{AgNp}$ synthesis is that they provide the combination of natural capping agents (such as amino acids, enzymes, polysaccharides, terpenoids, alkanoids, phenolics, and vitamins, etc.) for stabilization of AgNps in suspension (Ahmed et al., 2016). Recent research has reported the presence of many bioactive compounds in the aqueous/solvent leaf extracts of J. curcas responsible for synthesis, stabilization/capping of Jc-AgNps and also for its efficient antimicrobial activity (Kalimuthu et al., 2010; Ahirrao et al., 2011; Najda et al., 2013; Chauhan et al., 2015). The vibrational bands (FTIR) observed in the Jc-AgNps indicated the presence of various compounds (free amines, alkanoids, and flavonoids), which were earlier reported for synthesis and stabilization of nanoparticles (Gole et al., 2001; Lee et al., 2014; Joseph and Mathew, 2015).

The value of zeta potential is zero at iso-electric point proving its least stability, whereas the highly negative and positive zeta potential are considered to be more stable (Sadeghi and Gholamhoseinpoor, 2015) validating the high stability $(-23.4 \mathrm{mV})$ of synthesized Jc-AgNps in colloidal suspension. The spherical and irregular shaped nanoparticles of varied sizes could be attributed to difference in their formation timings as suggested in various studies (Kasthuri et al., 2009; Sadhasivam et al., 2010). Rajasekharreddy et al. (2010) have also synthesized AgNps from aqueous $J$. curcas leaf extract and reported the average particle size of $20 \mathrm{~nm}$. The present finding showed the average particle size of $43 \mathrm{~nm}$ (DLS) which is very close with the above. However, 

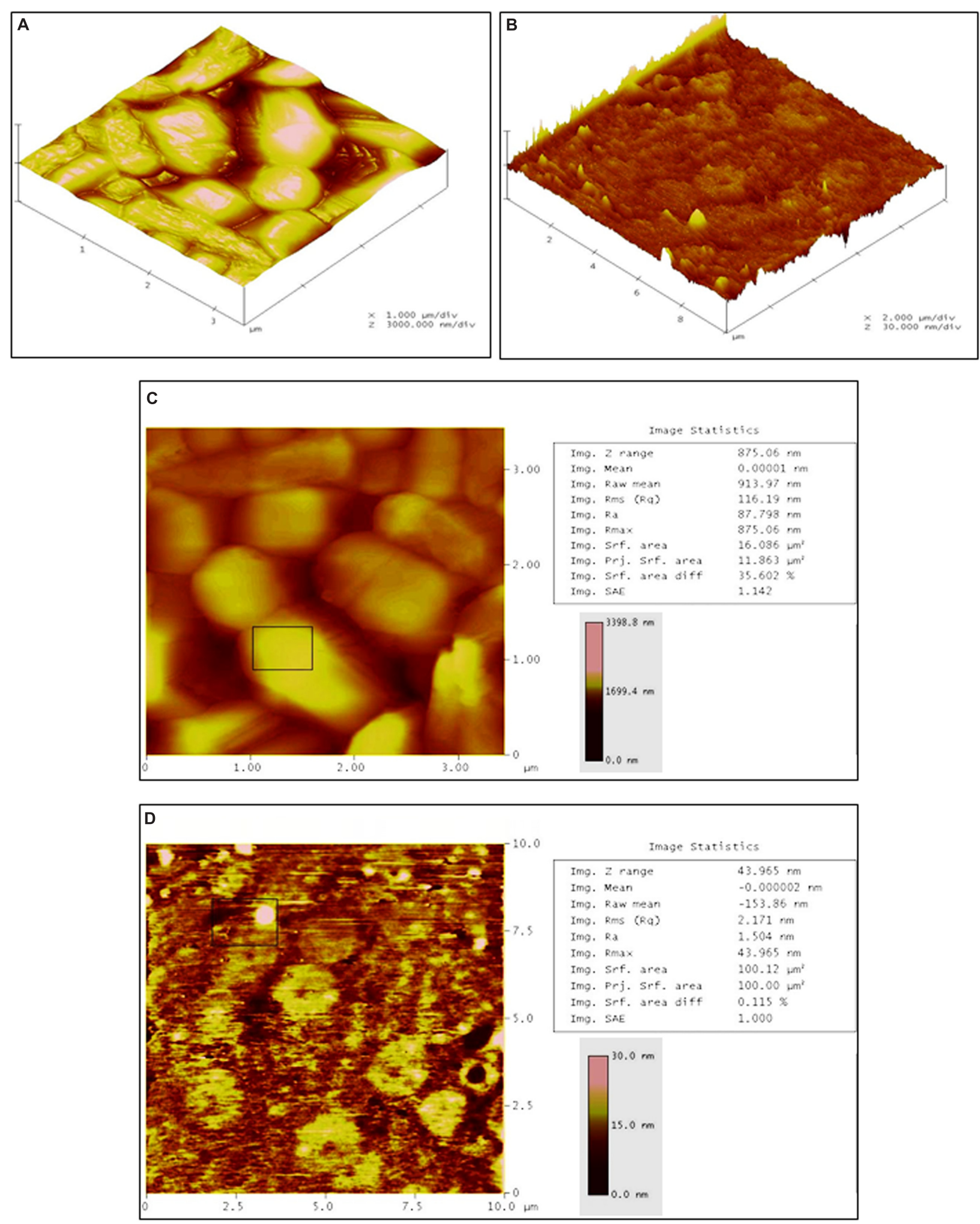

FIGURE 5 | Atomic force microscopic analysis. (A) Three dimensional section of untreated L. monocytogenes cells showing normal and smooth cell surfaces, (B) Three dimensional section of Jc-AgNps treated L. monocytogenes cells showing clear cell damage, (C) Image statistics of untreated $L$. monocytogenes cells (RMS: $116.19 \mathrm{~nm}$, height: $1699 \mathrm{~nm}$ ), (D) Image statistics of treated L. monocytogenes cells (RMS: $2.17 \mathrm{~nm}$, height:15 nm). 
more uniformity and smaller size in previous report can arise from controlled reaction rate and higher temperature conditions induced by incubation in sunlight as opposed to dark synthesis in our study. AFM more clearly depicts the agglomeration and actual size of nanoparticles. Previously, Hemath Naveen et al. (2010) used AFM to depict agglomeration and irregular surfaces of biologically formed nanoparticle. In contrast, the surface roughness properties (rms: 1.31) analyzed using AFM in current study showed smooth nanoparticles without any cracks.

The trend of inhibitory zone produced by Jc-AgNps showed that the Gram-negative bacteria were more sensitive than Grampositive bacterial strains. The highest ZOI was obtained with E. coli at $30 \mu \mathrm{l}(0.5 \mathrm{mg} / \mathrm{ml})$ followed by $P$. aeruginosa, making them more sensitive than the other bacteria tested in this study. Birla et al. (2009) reported that green synthesized AgNps enhanced the antimicrobial activity of antibiotics against $E$. coli and $P$. aeruginosa. Similarly, Sondi and Salopek-Sondi (2004) have observed $70 \%$ growth inhibition of E. coli cells at $10 \mu \mathrm{g} / \mathrm{cm}^{3}$ of silver nanoparticle. In another study, Awwad et al. (2012) have described the efficient antibacterial activity of Olea europaea leaf synthesized AgNps, suggesting L. monocytogenes (ZOI: $20 \mathrm{~mm}$ ) to be more sensitive than $S$. aureus (ZOI: $10 \mathrm{~mm}$ ) as displayed in the present study. Similar pattern for antibacterial potential of Jc-AgNps was observed using the microdilution method, where the MIC and MBC values for Gram-positive bacteria were higher than that for Gram-negative bacteria. Studies have pointed that thicker cell wall of Gram-positive bacteria protects the penetration of silver ions into cytoplasm, therefore the effect of AgNps is more pronounced in Gram-negative bacteria than Gram-positive bacteria (Feng et al., 2000; Shrivastava et al., 2007). This was further confirmed in the present study as the cells of S. enterica showed significant cell damage even at $1 / 2$ MIC level of Jc-AgNps, and at the MIC level only ghost like cell remains were observed under SEM examination. Although Jc-AgNps treated L. monocytogenes cells were observed to be deformed and shrunk, the damage was less pronounced than that in S. enterica cells.

The more comprehensible cell damage and clear penetration and interaction of silver nanoparticle with cell membrane was observed under TEM micrograph. The $48 \mathrm{~h} \mathrm{Jc-AgNps} \mathrm{treated}$ cells of L. monocytogenes showed complete cell distortion with visible Jc-AgNps surrounding damaged cell (Figure 4B). Reports have pointed the similar trend of interaction, penetration and damage of bacterial cells by AgNps (Xu et al., 2004; Raffi et al., 2008). Some previous studies (Tyagi and Malik, 2010) have assessed the AFM analysis to show distinctive change in cell surface and structure. It was observed that a remarkable decrease occurs in height and root mean square (pertaining to surface roughness) values of treated cells which is correlated with the observations of three dimensional modification in L. monocytogenes cells due to $\mathrm{Jc}-\mathrm{AgNps}$ treatments in the present study. Literature reports have suggested that the efficient activity of AgNps is due to its large surface area to attach with microorganisms (Umadevi et al., 2011; Ahmed et al., 2016). AgNps were believed to interact with sulfurcontaining proteins of membrane and also with phosphorous containing DNA of bacterial cell, thereby inhibiting cell division leading to cell death (Feng et al., 2000; Rai et al., 2009).

The antimicrobial activity of leaf (Kalimuthu et al., 2010), stem bark (Igbinosa et al., 2009), and roots (Arekemase et al., 2011) of J. curcas have been reported in various studies, but very few reports have used J. curcas for the synthesis of AgNps (Bar et al., 2009a,b; Rajasekharreddy et al., 2010). None of these reports have tested the antibacterial potential and interaction of synthesized Jc-AgNps with bacterial cells. Hence, the present study is relevant, as this is the first systematic report on antibacterial potential of Jc-AgNps against food borne microbes. Results can be useful for designing ways to control food borne pathogens. Some reports have exploited the potential of AgNps for food protection by preparing AgNps loaded food packaging materials with efficient antibacterial activity against $E$. coli and S. aureus (Tankhiwale and Bajpai, 2009; De Moura et al., 2012). However, these studies have employed chemical/physical methods for synthesizing AgNps which are quite expensive and potentially hazardous, especially for food application (Ahmed et al., 2016). Further research to use such green synthesized and stable AgNps for designing materials for varied applications is warranted.

\section{CONCLUSION}

The present study demonstrated significant antibacterial activity of $J$. curcas leaf extract (aqueous) synthesized silver nanoparticles (Jc-AgNps). The analytical techniques such as UV-vis, Zeta potential, SEM-EDX, XRD established the formation of stable crystalline AgNps, whereas spherical and irregular shape of Jc-AgNps (20-100 nm) was confirmed by AFM, SEM, TEM, and DLS analysis. The FTIR analysis gave strong indications about the involvement of various biological compounds responsible for formation and stabilization of Jc-AgNps in suspension. The synthesized Jc-AgNps showed significant bactericidal activity against Gram-positive and Gram-negative bacteria and were highly effective against E. coli. A detailed microscopic examination of $L$. monocytogenes using SEM and AFM showed a visible morphological distortion, whereas TEM clearly spotlighted the impact of Jc-AgNps on cell's ultrastructure, showing membrane pits, intracellular Jc-AgNps accumulation and cell damage in treated cells. The antibacterial potential of Jc-AgNps can be useful in designing need based applications in various sectors (Environment, healthcare, textiles, etc) i.e., water purification, nano-silver based antimicrobial paints/coatings, silver dressings for wound management, AgNp impregnated clothings which restricts the growth of odor causing bacteria.

\section{AUTHOR CONTRIBUTIONS}

$\mathrm{NC}, \mathrm{AT}$, and PK designed the experiments and performed the experiments. AT and AM kept eyes on data analysis and did the manuscript compilation. All authors reviewed the manuscript before submission. 


\section{ACKNOWLEDGMENTS}

The authors would like to thank Mr. Sumit, Prof. B.R Mehta and Mr. D. C Sharma, for providing AFM and SEM facility (IIT Delhi), respectively. We acknowledge the support provided by Mr. Sandeep Arya, Electron Microscopy, AIIMS, New Delhi, for TEM studies. One of the authors (NC) gratefully acknowledges RGNF, University Grants Commission (UGC), Government of India, for providing funds. We are also grateful to the technical staff, and the students of Applied Microbiology Lab, CRDT, IIT Delhi for their cooperation.

\section{SUPPLEMENTARY MATERIAL}

The Supplementary Material for this article can be found online at: http://journal.frontiersin.org/article/10.3389/fmicb. 2016.01748/full\#supplementary-material

\section{REFERENCES}

Abbassi, R., Yadav, A. K., Kumar, N., Huang, S., and Jaffe, P. R. (2013). Modeling and optimization of dye removal using "green" clay supported iron nanoparticles. Ecol. Eng. 61, 366-370. doi: 10.1016/j.ecoleng.2013.09.040

Afkhami, A., and Moosavi, R. (2010). Adsorptive removal of Congo red, a carcinogenic textile dye, from aqueous solutions by maghemite nanoparticles. J. hazard. Mater. 174, 398-403. doi: 10.1016/j.jhazmat.2009.09.066

Ahirrao, R. A., Patel, M. R., Pokal, D. M., Patil, J. K., and Suryawanshi, H. P. (2011). Phytochemical screening of leaves of Jatropha curcas plant. Int. J. Res. Ayurveda Pharm. 2, 1324-1327.

Ahmed, S., Ahmad, M., Swami, B. L., and Ikram, S. (2016). A review on plants extract mediated synthesis of silver nanoparticles for antimicrobial applications: a green expertise. J. Adv. Res. 7, 17-28. doi: 10.1016/j.jare.2015.02.007

Arekemase, M. O., Kayode, R. M. O., and Ajiboye, A. E. (2011). Antimicrobial activity and phytochemical analysis of Jatropha curcas plant against some selected microorganisms. Int. J. Biol. 3, 52.

Awwad, A. M., Salem, N. M., and Abdeen, A. O. (2012). Biosynthesis of silver nanoparticles using Olea europaea leaves extract and its antibacterial activity. Nanosci. Nanotechnol. 2, 164-170. doi: 10.5923/j.nn.20120206.03

Balaji, D. S., Basavaraja, S., Deshpande, R., Mahesh, D. B., Prabhakar, B. K., and Venkataraman, A. (2009). Extracellular biosynthesis of functionalized silver nanoparticles by strains of Cladosporium cladosporioides fungus. Colloids Surf. B 68, 88-92. doi: 10.1016/j.colsurfb.2008.09.022

Bar, H., Bhui, D. K., Sahoo, G. P., Sarkar, P., De, S. P., and Misra, A. (2009a). Green synthesis of silver nanoparticles using latex of Jatropha curcas. Colloids Surf. A Physicochem. Eng. Asp. 339, 134-139. doi: 10.1007/s00449-0141142-4

Bar, H., Bhui, D. K., Sahoo, G. P., Sarkar, P., Pyne, S., and Misra, A. (2009b). Green synthesis of silver nanoparticles using seed extract of Jatropha curcas. Colloids Surf. A Physicochem. Eng. Asp. 348, 212-216. doi: 10.1016/j.colsurfa.2009. 07.021

Behera, M., and Ram, S. (2013). Spectroscopy-based study on the interaction between gold nanoparticle and poly (vinylpyrrolidone) molecules in a nonhydrocolloid. Int. Nano Lett. 3, 1-7. doi: 10.1186/2228-5326-3-17

Berchmans, H. J., and Hirata, S. (2008). Biodiesel production from crude Jatropha curcas L. seed oil with a high content of free fatty acids. Bioresour. Technol. 99, 1716-1721. doi: 10.1016/j.biortech.2007.03.051

Birla, S. S., Tiwari, V. V., Gade, A. K., Ingle, A. P., Yadav, A. P., and Rai, M. K. (2009). Fabrication of silver nanoparticles by Phoma glomerata and its combined effect against Escherichia coli, Pseudomonas aeruginosa and Staphylococcus aureus. Lett. Appl. Microbiol. 48, 173-179. doi: 10.1111/j.1472765X.2008.02510.x
FIGURE S1 | (A) Three different tubes (1, 2, 3) monitored at 24, 48, and $72 \mathrm{~h}$ (Tube 1) $\mathrm{AgNO}_{3}$ solution (0.002 M), (Tube 2) Plant aqueous extract (Jatropha curcas leaves), (Tube 3) Synthesis of Jc-AgNps (plant extract with $0.002 \mathrm{M}$ AgNO3 solution in 1:10 ratio). (B) UV-vis absorption spectra of Jc-AgNPs synthesized at room temperature by treating $0.002 \mathrm{M} \mathrm{AgNO}_{3}$ with $\mathrm{J}$. curcas leaf extract at different time intervals (24, 48, and $72 \mathrm{~h})$.

FIGURE S2 | (A) Calibration curve of silver at different concentrations (2, 6, 8 ppm); (B) Quantification of silver in the sample (Jc-AgNp) by Microwave plasma-atomic emission spectrometry (MP-AES).

\section{FIGURE S3 | Physical characterization of green synthesized Jc-AgNps.}

(A) Size distribution by intensity dynamic light scattering (DLS); Z average $43.67 \mathrm{~nm}$ (diam.); (B) Zeta potential (-23.4 mV) distribution, (C) X-ray diffraction (XRD) patterns of Jc-AgNPs powder, (D) FTIR spectrum of vacuum dried powder of Jc-AgNPs.

FIGURE S4 | Scanning electron microscopic analysis (SEM), (A) SEM micrograph of untreated Salmonella enterica cells showing normal and well organized structure, (B) SEM micrograph of JC-AgNps treated ( $1 / 2 \mathrm{MIC})$ S. enterica cells showing deformation and aggregation, (C) SEM micrograph of Jc-AgNps treated (MIC) S. enterica cells showing extremely damaged remains.

Chauhan, N., Kumar, P., Mishra, S., Verma, S., Malik, A., and Sharma, S. (2015). Insecticidal activity of Jatropha curcas extracts against housefly, Musca domestica. Environ. Sci. Pollut. Res. 22, 14793-14800. doi: 10.1007/s11356-0154686-1

Daniel, M. C., and Astruc, D. (2004). Gold nanoparticles: assembly, supramolecular chemistry, quantum-size-related properties, and applications toward biology, catalysis, and nanotechnology. Chem. Rev. 104, 293-346. doi: $10.1021 /$ cr030698+

Das, B., Dash, S. K., Mandal, D., Ghosh, T., Chattopadhyay, S., Tripathy, S., et al. (2015). Green synthesized silver nanoparticles destroy multidrug resistant bacteria via reactive oxygen species mediated membrane damage. Arabian J. Chem. doi: 10.1016/j.arabjc.2015.08.008

de Faria, A. F., de Moraes, A. C. M., Marcato, P. D., Martinez, D. S. T., Durán, N., Souza Filho, A. G., et al. (2014). Eco-friendly decoration of graphene oxide with biogenic silver nanoparticles: antibacterial and antibiofilm activity. J. Nanopart. Res. 16, 1-16. doi: 10.1007/s11051-013-2110-7

De Moura, M. R., Mattoso, L. H., and Zucolotto, V. (2012). Development of cellulose-based bactericidal nanocomposites containing silver nanoparticles and their use as active food packaging. J. Food Eng. 109, 520-524. doi: 10.1016/j.jfoodeng.2011.10.030

Donnelly, C. W. (2001). Listeria monocytogenes: a continuing challenge. Nutr. Rev. 59, 183-194. doi: 10.1111/j.1753-4887.2001.tb07011.x

Dwivedi, N., Kumar, S., Dayal, S., Rauthan, C. M. S., and Panwar, O. S. (2011). Studies of nanostructured copper/hydrogenated amorphous carbon multilayer films. J. Alloys Compd. 509, 1285-1293. doi: 10.1016/j.jallcom.2010.10.016

Edison, T. J. I., and Sethuraman, M. G. (2012). Instant green synthesis of silver nanoparticles using Terminalia chebula fruit extract and evaluation of their catalytic activity on reduction of methylene blue. Process Biochem. 47, 1351-1357. doi: 10.1016/j.procbio.2012.04.025

Feng, Q. L., Wu, J., Chen, G. Q., Cui, F. Z., Kim, T. N., and Kim, J. O. (2000). A mechanistic study of the antibacterial effect of silver ions on Escherichia coli and Staphylococcus aureus. J. Biomed. Mater. Res. 52, 662-668. doi: 10.1002/1097-4636(20001215)52:4<662::AID-JBM10>3.0.CO;2-3

Forough, M., and Farhadi, K. (2010). Biological and green synthesis of silver nanoparticles. Turk. J. Eng. Env. Sci. 34, 281-287.

Gola, D., Dey, P., Bhattacharya, A., Mishra, A., Malik, A., Namburath, M., et al. (2016). Multiple heavy metal removal using an entomopathogenic fungi Beauveria bassiana. Bioresour. Technol. 218, 388-396. doi: 10.1016/j.biortech.2016.06.096

Gole, A., Dash, C., Ramakrishnan, V., Sainkar, S. R., Mandale, A. B., Rao, M., et al. (2001). Pepsin-gold colloid conjugates: preparation characterization and enzymatic activity. Langmuir 17, 1674-1679. doi: 10.1021/la0 01164w 
Gurunathan, S., Han, J. W., Eppakayala, V., Jeyaraj, M., and Kim, J. H. (2013). Cytotoxicity of biologically synthesized silver nanoparticles in MDAMB-231 human breast cancer cells. Biomed. Res. Int. 2013:535796. doi: $10.1155 / 2013 / 535796$

Hebbalalu, D., Lalley, J., Nadagouda, M. N., and Varma, R. S. (2013). Greener techniques for the synthesis of silver nanoparticles using plant extracts, enzymes, bacteria, biodegradable polymers, and microwaves. ACS Sustain. Chem. Eng. 1, 703-712. doi: 10.1021/sc4000362

Hemath Naveen, K. S., Kumar, G., Karthik, L., and Bhaskara Rao, K. V. (2010). Extracellular biosynthesis of silver nanoparticles using the filamentous fungus Penicillium sp. Arch. Appl. Sci. Res. 2, 161-167.

Igbinosa, O. O., Igbinosa, E. O., and Aiyegoro, O. A. (2009). Antimicrobial activity and phytochemical screening of stem bark extracts from Jatropha curcas (Linn). Afr. J. Pharm. Pharmacol. 3, 058-062.

Jayaprakash, N., Vijaya, J. J., and Kennedy, L. J. (2014). Microwave-assisted rapid facile synthesis, characterization and their antibacterial activity of PVP capped silver nanospheres. Synth. React. Inorg. M. 45, 1533-1538. doi: 10.1080/15533174.2013.862830

Joseph, S., and Mathew, B. (2015). Microwave assisted facile green synthesis of silver and gold nanocatalysts using the leaf extract of Aerva lanata. Spectrochim. Acta A Mol. Biomol. Spectrosc. 136, 1371-1379. doi: 10.1016/j.saa.2014. 10.023

Kalimuthu, K., Vijayakumar, S., and Senthilkumar, R. (2010). Antimicrobial activity of the biodiesel plant, Jatropha curcas L. Int. J. Pharm. Biol. Sci. 1, 1-5. doi: 10.1016/j.ecoenv.2011.11.002

Kasthuri, J., Veerapandian, S., and Rajendiran, N. (2009). Biological synthesis of silver and gold nanoparticles using apiin as reducing agent. Colloids Surf. B 68, 55-60. doi: 10.1016/j.colsurfb.2008.09.021

Kim, S. H., Lee, H. S., Ryu, D. S., Choi, S. J., and Lee, D. S. (2011). Antibacterial activity of silver-nanoparticles against Staphylococcus aureus and Escherichia coli. Korean J. Microbiol. Biotechnol. 39, 77-85.

Lee, J., Park, E. Y., and Lee, J. (2014). Non-toxic nanoparticles from phytochemicals: preparation and biomedical application. Bioprocess Biosyst. Eng. 37, 983-989. doi: 10.1007/s00449-013-1091-3

Lok, C. N., Ho, C. M., Chen, R., He, Q. Y., Yu, W. Y., Sun, H., et al. (2006). Proteomic analysis of the mode of antibacterial action of silver nanoparticles. J. Proteome Res. 5, 916-924. doi: 10.1021/pr0504079

Mariselvam, R., Ranjitsingh, A. J. A., Nanthini, A. U. R., Kalirajan, K., Padmalatha, C., and Selvakumar, P. M. (2014). Green synthesis of silver nanoparticles from the extract of the inflorescence of Cocos nucifera (Family: Arecaceae) for enhanced antibacterial activity. Spectrochim. Acta A Mol. Biomol. Spectrosc. 129, 537-541. doi: 10.1016/j.saa.2014. 03.066

Morones, J. R., Elechiguerra, J. L., Camacho, A., Holt, K., Kouri, J. B., Ramírez, J. T., et al. (2005). The bactericidal effect of silver nanoparticles. Nanotechnology 16, 2346. doi: 10.1088/0957-4484/16/10/059

Muthukrishnan, S., Bhakya, S., Kumar, T. S., and Rao, M. V. (2015). Biosynthesis, characterization and antibacterial effect of plant-mediated silver nanoparticles using Ceropegia thwaitesii-An endemic species. Ind. Crop Prod. 63, 119-124. doi: 10.1016/j.indcrop.2014.10.022

Najda, A., Almehemdi, A. F., and Zabar, A. F. (2013). Chemical composition and nutritional value of jatropha (Jatropha curcas L.) leaves. J. Genet. Environ. Resour. Conserv. 1, 221-226.

Osoniyi, O., and Onajobi, F. (2003). Coagulant and anticoagulant activities in Jatropha curcas latex. J. Ethnopharmacol. 89, 101-105. doi: 10.1016/S03788741(03)00263-0

Porel, S., Singh, S., Harsha, S. S., Rao, D. N., and Radhakrishnan, T. P. (2005). Nanoparticle-embedded polymer: in situ synthesis, free-standing films with highly monodisperse silver nanoparticles and optical limiting. Chem. Mat. 17, 9-12. doi: $10.1021 / \mathrm{cm} 0485963$

Prathna, T. C., Chandrasekaran, N., Raichur, A. M., and Mukherjee, A. (2011). Biomimetic synthesis of silver nanoparticles by Citrus limon (lemon) aqueous extract and theoretical prediction of particle size. Colloids Surf. B 82, 152-159. doi: 10.1016/j.colsurfb.2010.08.036

Raffi, M., Hussain, F., Bhatti, T. M., Akhter, J. I., Hameed, A., and Hasan, M. M. (2008). Antibacterial characterization of silver nanoparticles against $E$. coli ATCC-15224. J. Mater. Sci. Technol. 24, 192-196.
Rai, M., Yadav, A., and Gade, A. (2009). Silver nanoparticles as a new generation of antimicrobials. Biotech. Adv. 27, 76-83. doi: 10.1016/j.biotechadv.2008.09.002

Rajakannu, S., Shankar, S., Perumal, S., Subramanian, S., and Dhakshinamoorthy, G. P. (2015). Biosynthesis of silver nanoparticles using Garcinia mangostana fruit extract and their antibacterial, antioxidant activity. Int. J. Curr. Microbiol. Appl. Sci. 4, 944-952.

Rajasekharreddy, P., Rani, P. U., and Sreedhar, B. (2010). Qualitative assessment of silver and gold nanoparticle synthesis in various plants: a photobiological approach. J. Nanopart Res. 12, 1711-1721. doi: 10.1007/s11051-010-9894-5

Roy, K., Sarkar, C. K., and Ghosh, C. K. (2014). Plant-mediated synthesis of silver nanoparticles using parsley (Petroselinum crispum) leaf extract: spectral analysis of the particles and antibacterial study. Appl. Nanosci. 5, 945-951. doi: 10.1007/s13204-014-0393-3

Sadeghi, B., and Gholamhoseinpoor, F. (2015). A study on the stability and green synthesis of silver nanoparticles using Ziziphora tenuior $(\mathrm{Zt})$ extract at room temperature. Spectrochim. Acta A Mol. Biomol. Spectrosc. 134, 310-315. doi: 10.1016/j.saa.2014.06.046

Sadhasivam, S., Shanmugam, P., and Yun, K. (2010). Biosynthesis of silver nanoparticles by Streptomyces hygroscopicus and antimicrobial activity against medically important pathogenic microorganisms. Colloids Surf. B 81, 358-362. doi: 10.1016/j.colsurfb.2010.07.036

Salem, W. M., Haridy, M., Sayed, W. F., and Hassan, N. H. (2014). Antibacterial activity of silver nanoparticles synthesized from latex and leaf extract of Ficus sycomorus. Ind. Crop Prod. 62, 228-234. doi: 10.1016/j.indcrop.2014. 08.030

Samuel, U., and Guggenbichler, J. P. (2004). Prevention of catheter-related infections: the potential of a new nano-silver impregnated catheter. Int. J. Antimicrob. Agents 23, 75-78. doi: 10.1016/j.ijantimicag.2003.12.004

Shrivastava, S., Bera, T., Roy, A., Singh, G., Ramachandrarao, P., and Dash, D. (2007). Characterization of enhanced antibacterial effects of novel silver nanoparticles. Nanotechnology 18, 225103. doi: 10.1088/0957$4484 / 18 / 22 / 225103$

Singh, M., Singh, S., Prasad, S., and Gambhir, I. S. (2008). Nanotechnology in medicine and antibacterial effect of silver nanoparticles. Dig. J. Nanomater. Biostruct. 3, 115-122.

Sondi, I., and Salopek-Sondi, B. (2004). Silver nanoparticles as antimicrobial agent: a case study on E. coli as a model for Gram-negative bacteria. J. Colloid Interface Sci. 275, 177-182. doi: 10.1016/j.jcis.2004.02.012

SPSS (2008). Statistical Product and Service Solution. System user's Guide, Version 17.5. Available at: http://www.winwrap.com/

Sre, P. R., Reka, M., Poovazhagi, R., Kumar, M. A., and Murugesan, K. (2015). Antibacterial and cytotoxic effect of biologically synthesized silver nanoparticles using aqueous root extract of Erythrina indica lam. Spectrochim. Acta A Mol. Biomol. Spectrosc. 135, 1137-1144. doi: 10.1016/j.saa.2014.08.019

Tankhiwale, R., and Bajpai, S. K. (2009). Graft copolymerization onto cellulosebased filter paper and its further development as silver nanoparticles loaded antibacterial food-packaging material. Colloids Surf. B 69, 164-168. doi: 10.1016/j.colsurfb.2008.11.004

Tapanes, N. C. O., Aranda, D. A. G., de Mesquita Carneiro, J. W., and Antunes, O. A. C. (2008). Transesterification of Jatropha curcas oil glycerides: theoretical and experimental studies of biodiesel reaction. Fuel. 87, 2286-2295. doi: 10.1016/j.fuel.2007.12.006

Tsunoyama, H., Sakurai, H., Ichikuni, N., Negishi, Y., and Tsukuda, T. (2004). Colloidal gold nanoparticles as catalyst for carbon-carbon bond formation: application to aerobic homocoupling of phenylboronic acid in water. Langmuir 20, 11293-11296. doi: 10.1021/la0478189

Tyagi, A. K., and Malik, A. (2010). In situ SEM, TEM and AFM studies of the antimicrobial activity of lemon grass oil in liquid and vapour phase against Candida albicans. Micron 41, 797-805. doi: 10.1016/j.micron.2010. 05.007

Tyagi, A. K., and Malik, A. (2011). Antimicrobial potential and chemical composition of Mentha piperita oil in liquid and vapour phase against food spoiling microorganisms. Food Control 22, 1707-1714. doi: 10.1016/j.foodcont.2011.04.002

Umadevi, M., Rani, T., Balakrishnan, T., and Ramanibai, R. (2011). Antimicrobial activity of silver nanoparticles prepared under an ultrasonic field. Int. J. Pharm. Sci. Nanotech. 4, 1491-1496. 
Verma, S., Verma, M., Sharma, S., and Malik, A. (2013). Determination of phytocomponents of Jatropha curcas root by GC-MS analysis and their termiticidal activity. Int. J. Ecol. Environ. Sci. 39, 159-169.

Wen, H. C., Lin, Y. N., Jian, S. R., Tseng, S. C., Weng, M. X., Liu, Y. P., et al. (2007). Observation of growth of human fibroblasts on silver nanoparticles. J. Phys. 61, 445.

Xu, X. H. N., Brownlow, W. J., Kyriacou, S. V., Wan, Q., and Viola, J. J. (2004). Real-time probing of membrane transport in living microbial cells using single nanoparticle optics and living cell imaging. Biochemistry 43, 10400-10413. doi: 10.1021/bi036231a

Yehia, R. S., and Al-Sheikh, H. (2014). Biosynthesis and characterization of silver nanoparticles produced by Pleurotus ostreatus and their anticandidal and anticancer activities. World J. Microbiol. Biotechnol. 30, 2797-2803. doi: 10.1007/s11274-014-1703-3
Yeo, S. Y., and Jeong, S. H. (2003). Preparation and characterization of polypropylene/silver nanocomposite fibers. Polym. Int. 52, 1053-1057. doi: 10.1002/pi.1215

Conflict of Interest Statement: The authors declare that the research was conducted in the absence of any commercial or financial relationships that could be construed as a potential conflict of interest.

Copyright (c) 2016 Chauhan, Tyagi, Kumar and Malik. This is an open-access article distributed under the terms of the Creative Commons Attribution License (CC BY). The use, distribution or reproduction in other forums is permitted, provided the original author(s) or licensor are credited and that the original publication in this journal is cited, in accordance with accepted academic practice. No use, distribution or reproduction is permitted which does not comply with these terms. 